\title{
Fibrinolytic response to moderate exercise in young male diabetics and non-diabetics
}

\author{
J. D. CASH AND R. C. MCGILL
}

From the South-east Scotland Regional Blood Transfusion Research Laboratories and the Diabetic Department? Royal Infirmary, Edinburgh

SYNOPSIS The euglobulin lysis time was measured in 25 young male insulin-dependent diabetic and 25 age- and sex-matched healthy controls before and after a standardized moderate treadmilt exercise procedure. There was a statistically significant mean shorter resting euglobulin lysis time in the diabetic group but their ability to respond to the exercise procedure was significantly impaired? It is suggested that this impaired fibrinolytic reactivity may be related to the diminished vaso-active reactivity previously reported in young diabetics.

Earlier studies, reported from this laboratory, on the fibrinolytic response to such stimulants as exercise and intravenous adrenaline demonstrated that in normal subjects it was possible to isolate a subgroup whose ability to generate plasminogen activator to these short stimuli appeared to be impaired (Cash, 1966; Cash and Allan, 1967). It was proposed that these individuals might be at risk to conditions such as atherosclerosis, thrombosis, and shock in which defective fibrinolysis has been considered to be an aetiological factor (Astrup, 1956; McKay, 1965; Hardaway, 1966). Atheroma is particularly common in diabetes, in which condition its consequences are responsible for much of the morbidity and mortality. Thus the following communication is a logical extension of our earlier studies in which the fibrinolytic response to exercise is compared between a group of young male insulindependent diabetics and age- and sex-matched controls.

\section{SUBJECTS AND METHODS}

Table I gives the clinical data of 25 insulin-dependent diabetics aged 19 to 30 years (mean: $25 \cdot 0 \pm 3.8$ ), who were willing to participate in the study. The 25 healthy male control subjects were undergraduates and colleagues aged 18 to 30 years (mean: $26 \cdot 2 \pm 2 \cdot 9$ ).

Experiments were performed in a procedure room at a temperature of 19 to $20^{\circ} \mathrm{C}$ between 9.00 am and 12 noon. The diabetic patients were requested to take their usual breakfast and morning dose of insulin. All subjects

Received for publication 31 May 1968. abstained from smoking and excessive exercise on the morning of the procedure and a pre-exercise rest foi 30 minutes was obligatory. The exercise consisted of walking on a treadmill moving at $3.4 \mathrm{mph}$ at $5^{\circ}$ elevatio for eight minutes. Cubital venous blood samples wero withdrawn, with the minimum of venous occlusionم immediately before and after the exercise and the level of circulating plasminogen activator was assayed by the euglobulin lysis time (Cash, 1966). All subjects were studied on more than one occasion and the interval? between each visit was at least one week. The percentage fibrinolytic response was calculated as $\mathrm{A}-\mathrm{B} / \mathrm{A} \times 100$. where $A$ and $B$ represented the resting and post-exercise euglobulin lysis times, respectively.

RESULTS

Details of the results of all subjects are shown in Table II and the frequency distribution of the fibrinolytic responses in Figure 1. The mean resting euglobulin lysis time in the diabetic and non-diabetio population was $119 \pm 104$ minutes and $203 \pm 158$ minutes, respectively. The difference between these values was highly significant $(\mathrm{t}=3.601, \mathrm{P}<0.001) \mathrm{\omega}$ Although there was a higher resting level of cir? culating plasminogen activator in the diabetic patients, it was possible to isolate a subgroup of poor responders $(<20 \%)$ and their mean percentage ${ }^{+}$ response $(31 \cdot 7 \pm 8.3)$ was significantly less than the normal controls $(39 \cdot 7 \pm 11 \cdot 5)(t=2 \cdot 786,0.005<$ 要 $<0.01)$. In both populations there was no correlatiom between the fibrinolytic responses to the exercis procedure and the resting levels of plasminoger activator as measured by the euglobulin lysis time 
TABLE I

CLINICAL DETAILS OF DIABETIC SUBJECTS

\begin{tabular}{|c|c|c|c|c|c|}
\hline \multirow{2}{*}{$\begin{array}{l}\text { Subject } \\
\text { No. }\end{array}$} & \multirow{2}{*}{ Age (yr) } & \multirow{2}{*}{$\begin{array}{l}\text { Duration of } \\
\text { Diabetes }(y r)\end{array}$} & \multicolumn{2}{|c|}{ Insulin Requirement (Units) ${ }^{3}$} & \multirow{2}{*}{$\begin{array}{l}\text {-Diabetic } \\
\text { Complications }\end{array}$} \\
\hline & & & Morning & Afternoon & \\
\hline 1 & 26 & 14 & 16 sol, 28 PZI & 一 & None \\
\hline 2 & 24 & 4 & 28 sol, $48 \mathrm{PZI}$ & - & None \\
\hline 3 & 22 & 12 & 8 sol, 40 PZI & $6 \mathrm{sol}$ & Albuminuria \\
\hline 4 & 29 & 3 & 44 sol, 56 PZI & - & None \\
\hline 5 & 30 & 4 & 32 sol, 56 PZI & - & None \\
\hline 6 & 30 & 8 & 40 sol, 40 PZI & - & Diabetic retinopathy \\
\hline 7 & 22 & 3 & 16 sol, 24 PZI & 20 sol & None \\
\hline 8 & 26 & 3 & 30 sol, 40 PZI & - & None \\
\hline 9 & 30 & 7 & 16 sol, 32 PZI & $18 \mathrm{sol}$ & None \\
\hline 10 & 30 & 16 & 12 sol, $36 \mathrm{PZI}$ & - & Diabetic retinopathy \\
\hline 11 & 20 & 4 & 24 sol, $40 \mathrm{PZI}$ & 16 sol & None \\
\hline $12^{1}$ & 29 & 15 & 32 sol, 32 SL & 32 sol, $32 \mathrm{SL}$ & Diabetic retinopathy \\
\hline 13 & 20 & 3 & 8 sol, 36 PZI & - & Diabetic retinopathy \\
\hline 14 & 28 & 5 & 12 sol, $16 \mathrm{PZI}$ & - & None \\
\hline 15 & 21 & 3 & 24 sol, $40 \mathrm{PZI}$ & 一 & None \\
\hline 16 & 20 & 6 & 10 sol, $24 \mathrm{PZI}$ & - & None \\
\hline $17^{2}$ & 24 & 1 & 24 sol, 32 PZI & 一 & None \\
\hline 18 & 28 & 17 & 24 sol, 40 PZI & - & Albuminuria \\
\hline 19 & 27 & 11 & 20 sol, $40 \mathrm{PZI}$ & 24 sol & Diabetic retinopathy \\
\hline 20 & 22 & 3 & 20 sol, 36 PZI & - & Diabetic retinopathy \\
\hline 21 & 23 & 1 & 16 sol, 16 PZI & - & None \\
\hline 22 & 19 & 13 & 56 sol, 44 PZI & 一 & Albuminuria \\
\hline 23 & 28 & 10 & 20 sol, 80 PZI & - & $\begin{array}{l}\text { Diabetic retinopathy } \\
\text { and albuminuria }\end{array}$ \\
\hline 24 & 22 & 1 & 12 sol, $12 \mathrm{PZI}$ & 一 & None \\
\hline 25 & 24 & 9 & 8 sol, 40 PZI & - & None \\
\hline
\end{tabular}

1 Insulin resistance treated with prednisolone $5 \mathrm{mg} \mathrm{bd}$

2 Epileptic: well controlled by phenobarbitone $30 \mathrm{mg}$ tds

3 The numbers represent the units of either soluble (sol), zinc protamine (PZI) or semi lente (SL) insuiin.

\section{DISCUSSION}

There is little agreement between the results of previous studies on the resting level of spontaneous fibrinolysis in diabetic patients. This may be due to the heterogeneity of the fibrinolytic assays employed and the populations of diabetics studied. Hathorn, Gillman, and Campbell (1961) and Fearnley, Chakrabarti, and Avis (1963) demonstrated lower spontaneous fibrinolysis compared with age-matched controls, whereas Denborough and Patterson (1962), MacKay and Hume (1964), and Tanser (1967) obser-

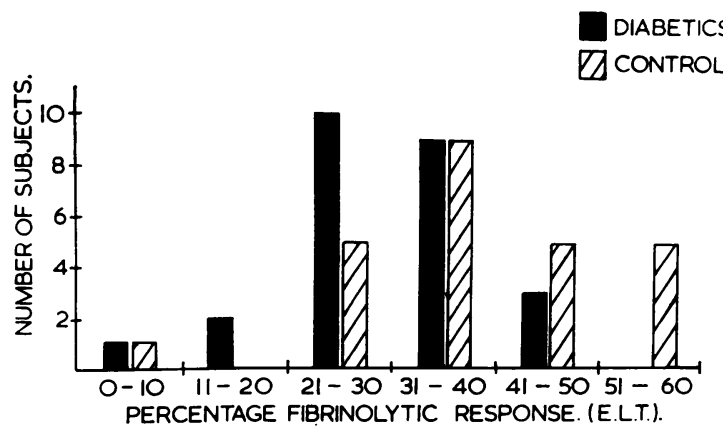

FIG. 1. The frequency distribution of percentage fibrinolytic response to moderate exercise in young diabetic subjects and controls. ved no difference between their diabetic patients and normal controls. Our finding of a significantly higher level of circulating plasminogen activator in these young male diabetic patients compared with the ageand sex-matched controls is difficult to explain. It may be of some significance that the group of diabetics we studied was more homogeneous in terms of age, sex, and insulin-dependence than in earlier studies, although MacKay and Hume (1964) found no significant difference between diabetics aged more or less than 45 years of age. The euglobulin lysis time is perhaps the best method readily available for the assay of circulating plasminogen activator (Fearnley, 1965), and the assays employed in other studies were less specific. However, as we are uncertain whether all antifibrinolytic substances are absent from precipitated euglobulin, the finding of Sandberg, Muller, Bellet, Feinberg, Gagnon, and Gelber (1963) of a markedly diminished plasma antifibrinolytic activity in diabetics receiving insulin may have contributed to our findings.

The biological significance of an increased resting level of plasminogen activator is not clear but Egeberg (1963), in a study of 30 diabetics, 24 of whom were on insulin therapy, demonstrated a relative hypercoagulability in vitro in terms of a shorter average plasma cephalin time and an average increase of antihaemophilic globulin of $70 \%$, 
TABLE II

EUGLOBULIN LYSIS TIME BEFORE AND AFTER MODERATE EXERCISE IN 25 YOUNG MALE DIABETICS AND 25 yOUNG MALF CONTROLS

\begin{tabular}{|c|c|c|c|c|c|c|c|c|}
\hline \multirow{3}{*}{$\begin{array}{l}\text { Subject } \\
\text { No. }\end{array}$} & \multicolumn{4}{|c|}{ Diabetics } & \multicolumn{4}{|c|}{ Controls } \\
\hline & \multicolumn{4}{|c|}{ Euglobulin Lysis Time } & \multicolumn{4}{|c|}{ Euglobulin Lysis Time } \\
\hline & Before & After & $\begin{array}{l}\text { Incr } \\
(\%)\end{array}$ & ease & Before & After & $\begin{array}{l}\text { Incr } \\
(\%)\end{array}$ & rease \\
\hline \multirow[t]{3}{*}{1} & 88 & 55 & 38 & & 140 & 71 & 49 & \\
\hline & 81 & 54 & 33 & 35 & 660 & 332 & 50 & 49 \\
\hline & 69 & 45 & 35 & & 500 & 257 & 49 & \\
\hline \multirow[t]{3}{*}{2} & 101 & 65 & 36 & & 240 & 110 & 54 & \\
\hline & 117 & 92 & 21 & 28 & 304 & 136 & 55 & 55 \\
\hline & 110 & 80 & 27 & & & & & \\
\hline \multirow[t]{6}{*}{3} & 69 & 47 & 32 & & 195 & 120 & 48 & \\
\hline & 80 & 59 & 26 & 27 & 105 & 58 & 45 & \\
\hline & 133 & 101 & 24 & & 135 & 80 & 40 & 43 \\
\hline & & & & & 77 & 45 & 42 & 43 \\
\hline & & & & & 83 & 51 & 39 & \\
\hline & & & & & 148 & 92 & 38 & \\
\hline \multirow[t]{5}{*}{4} & 93 & 53 & 44 & & 620 & 440 & 29 & \\
\hline & 78 & 44 & 44 & 40 & 84 & 60 & 29 & \\
\hline & 141 & 50 & 33 & & 270 & 200 & 26 & 29 \\
\hline & & & & & 318 & 213 & 33 & \\
\hline & & & & & 210 & 156 & 26 & \\
\hline \multirow[t]{5}{*}{5} & 61 & 41 & 20 & & 61 & 35 & 43 & \\
\hline & 62 & 52 & 16 & 20 & 75 & 42 & 44 & \\
\hline & 66 & 50 & 24 & & 57 & 35 & 39 & 37 \\
\hline & & & & & 65 & 45 & 31 & \\
\hline & & & & & 81 & 50 & 38 & \\
\hline \multirow[t]{3}{*}{6} & 138 & 71 & 49 & & 115 & 70 & 39 & \\
\hline & 165 & 71 & 57 & 49 & 146 & 96 & 34 & 37 \\
\hline & 83 & 50 & 40 & & & & & \\
\hline \multirow[t]{4}{*}{7} & 75 & 50 & 33 & & 105 & 60 & 43 & \\
\hline & 81 & 45 & 44 & 38 & 131 & 78 & 41 & \\
\hline & 65 & 40 & 39 & & 77 & 47 & 39 & 39 \\
\hline & & & & & 76 & 50 & 34 & \\
\hline \multirow[t]{3}{*}{8} & 108 & 57 & 48 & & 550 & 440 & 20 & \\
\hline & 114 & 66 & 34 & 41 & 211 & 172 & 19 & 24 \\
\hline & 147 & 84 & 43 & & 745 & 505 & 32 & \\
\hline \multirow[t]{3}{*}{9} & 83 & 64 & 23 & 27 & 143 & 60 & 58 & \\
\hline & 90 & 63 & 30 & 27 & 150 & 65 & 57 & 58 \\
\hline & & & & & 150 & 62 & 59 & \\
\hline \multirow[t]{3}{*}{10} & 79 & 50 & 37 & & 105 & 63 & 40 & \\
\hline & 117 & 74 & 31 & 36 & 95 & 59 & 38 & 40 \\
\hline & 91 & 55 & 40 & & 103 & 60 & 42 & \\
\hline \multirow[t]{3}{*}{11} & 95 & 61 & 36 & & 255 & 124 & 51 & \\
\hline & 126 & 81 & 36 & 33 & 315 & 153 & 51 & 51 \\
\hline & 86 & 62 & 28 & & 262 & 129 & 51 & \\
\hline \multirow[t]{2}{*}{12} & 508 & 398 & 22 & & 120 & 95 & 21 & \\
\hline & 340 & 278 & 19 & 21 & 159 & 116 & 27 & \\
\hline
\end{tabular}

\begin{tabular}{|c|c|c|c|c|c|c|c|c|}
\hline \multirow{3}{*}{$\begin{array}{l}\text { Subject } \\
\text { No. }\end{array}$} & \multicolumn{4}{|c|}{ Diabetics } & \multicolumn{4}{|c|}{ Controls } \\
\hline & \multicolumn{4}{|c|}{ Euglobulin Lysis Time } & \multicolumn{4}{|c|}{ Euglobulin Lysis Time } \\
\hline & Before & After & $\begin{array}{l}\text { Incr } \\
(\%)\end{array}$ & rease & Before & After & $\begin{array}{l}\text { Incr } \\
(\%)\end{array}$ & rease \\
\hline 12 & 635 & 494 & 22 & & $\begin{array}{l}272 \\
151 \\
245 \\
132\end{array}$ & $\begin{array}{r}192 \\
106 \\
185 \\
98\end{array}$ & $\begin{array}{l}29 \\
30 \\
24 \\
26\end{array}$ & 26 \\
\hline 13 & $\begin{array}{r}105 \\
72\end{array}$ & $\begin{array}{l}70 \\
52\end{array}$ & $\begin{array}{l}33 \\
28\end{array}$ & 30 & $\begin{array}{l}494 \\
720 \\
274\end{array}$ & $\begin{array}{l}211 \\
370 \\
137\end{array}$ & $\begin{array}{l}57 \\
48 \\
50\end{array}$ & 52 \\
\hline 14 & $\begin{array}{l}72 \\
75\end{array}$ & $\begin{array}{l}52 \\
45\end{array}$ & $\begin{array}{l}28 \\
40\end{array}$ & 33 & $\begin{array}{l}100 \\
113 \\
110\end{array}$ & $\begin{array}{l}54 \\
56 \\
52\end{array}$ & $\begin{array}{l}46 \\
50 \\
53\end{array}$ & 50 \\
\hline 15 & $\begin{array}{l}212 \\
146\end{array}$ & $\begin{array}{l}145 \\
104\end{array}$ & $\begin{array}{l}32 \\
29\end{array}$ & 30 & $\begin{array}{l}112 \\
223 \\
180\end{array}$ & $\begin{array}{r}52 \\
104 \\
80\end{array}$ & $\begin{array}{l}54 \\
53 \\
56\end{array}$ & 54 \\
\hline 16 & $\begin{array}{l}62 \\
68 \\
60\end{array}$ & $\begin{array}{l}36 \\
56 \\
55\end{array}$ & $\begin{array}{l}42 \\
18 \\
31\end{array}$ & 30 & $\begin{array}{l}257 \\
120 \\
140\end{array}$ & $\begin{array}{r}143 \\
80 \\
90\end{array}$ & $\begin{array}{l}44 \\
33 \\
36\end{array}$ & 38 \\
\hline 17 & $\begin{array}{l}69 \\
70\end{array}$ & $\begin{array}{l}46 \\
47\end{array}$ & $\begin{array}{l}33 \\
33\end{array}$ & 33 & $\begin{array}{r}72 \\
108 \\
200 \\
320\end{array}$ & $\begin{array}{r}65 \\
86 \\
184 \\
310\end{array}$ & $\begin{array}{r}10 \\
20 \\
8 \\
3\end{array}$ & 10 \\
\hline 18 & $\begin{array}{l}91 \\
93 \\
95\end{array}$ & $\begin{array}{l}58 \\
73 \\
55\end{array}$ & $\begin{array}{l}36 \\
22 \\
42\end{array}$ & 33 & $\begin{array}{l}189 \\
270\end{array}$ & $\begin{array}{r}59 \\
137\end{array}$ & $\begin{array}{l}5 \\
48 \\
49\end{array}$ & 49 \\
\hline 19 & $\begin{array}{l}80 \\
80\end{array}$ & $\begin{array}{l}47 \\
54\end{array}$ & $\begin{array}{l}42 \\
32\end{array}$ & 37 & $\begin{array}{l}65 \\
84 \\
94\end{array}$ & $\begin{array}{l}51 \\
56 \\
64\end{array}$ & $\begin{array}{l}22 \\
33 \\
32\end{array}$ & 29 \\
\hline 20 & $\begin{array}{l}63 \\
64 \\
70\end{array}$ & $\begin{array}{l}39 \\
39 \\
50\end{array}$ & $\begin{array}{l}38 \\
39 \\
29\end{array}$ & 35 & $\begin{array}{l}250 \\
230\end{array}$ & $\begin{array}{l}160 \\
150\end{array}$ & $\begin{array}{l}36 \\
35\end{array}$ & 36 \\
\hline 21 & $\begin{array}{l}79 \\
81\end{array}$ & $\begin{array}{l}58 \\
48\end{array}$ & $\begin{array}{l}27 \\
41\end{array}$ & 34 & $\begin{array}{l}116 \\
108 \\
110\end{array}$ & $\begin{array}{l}87 \\
82 \\
85\end{array}$ & $\begin{array}{l}25 \\
24 \\
23\end{array}$ & 24 \\
\hline 22 & $\begin{array}{r}104 \\
88 \\
73\end{array}$ & $\begin{array}{l}73 \\
60 \\
60\end{array}$ & $\begin{array}{l}30 \\
32 \\
18\end{array}$ & 27 & $\begin{array}{l}120 \\
500\end{array}$ & $\begin{array}{r}75 \\
300\end{array}$ & $\begin{array}{l}38 \\
40\end{array}$ & 39 \\
\hline 23 & $\begin{array}{l}97 \\
98\end{array}$ & $\begin{array}{l}85 \\
93\end{array}$ & $\begin{array}{r}12 \\
5\end{array}$ & 9 & $\begin{array}{l}174 \\
135 \\
100\end{array}$ & $\begin{array}{l}89 \\
77 \\
60\end{array}$ & $\begin{array}{l}49 \\
43 \\
40\end{array}$ & 44 \\
\hline 24 & $\begin{array}{l}305 \\
400\end{array}$ & $\begin{array}{l}240 \\
325\end{array}$ & $\begin{array}{l}21 \\
19\end{array}$ & 20 & $\begin{array}{l}539 \\
269\end{array}$ & $\begin{array}{l}324 \\
162\end{array}$ & $\begin{array}{l}40 \\
40\end{array}$ & 40 \\
\hline 25 & $\begin{array}{l}91 \\
75\end{array}$ & $\begin{array}{l}53 \\
46\end{array}$ & $\begin{array}{l}42 \\
39\end{array}$ & 41 & $\begin{array}{r}107 \\
76 \\
95\end{array}$ & $\begin{array}{l}63 \\
45 \\
60\end{array}$ & $\begin{array}{l}42 \\
41 \\
37\end{array}$ & 40 \\
\hline
\end{tabular}

proaccelerin of $23 \%$, and fibrinogen of $44 \%$ above the average controls. It is possible that the high level of plasminogen activator is a physiological response to this relative hypercoagulability.

Although the mean resting levels of plasminogen activator in the diabetic population appeared to be higher than those of the controls, their ability to generate plasminogen activator to the exercise was diminished. This finding is contrary to that of Tanser (1967), who studied a group of 30 diabetics and observed no significant difference in their fibrinolytic response with an age-matched control group following a subcutaneous injection of adrenaline. However, only $10 \%$ of Tanser's patients were

below 30 years of age and it is possible that many of the others were not insulin-dependent. Furthermore, $\mathbb{N}$ the many variable factors known to govern adsorp- $N$ tion of subcutaneously administered drugs (Goodman and Gilman, 1965) may have contributed to $\omega$ this finding. It is also possible that the relatively? short duration of the fibrinolytic stimuli in oure experiments may be relevant, for we have demonstrated in healthy subjects that some poor ${ }^{-}$ fibrinolytic responders to a short period of exercise $\frac{7}{\circ}$ will respond normally to a more prolonged procedure $\frac{\mathbb{D}}{\overparen{D}}$ (Cash and Woodfield, 1967). Although adrenaline $\stackrel{?}{\mathbb{P}}$ is probably responsible, in part, for the fibrinolytic $\varrho$ response to exercise, there is no evidence that 
diabetics are less able to release catecholamines following exercise (Larsson, Persson, Sterky, and Thoren, 1964). It is generally assumed that the mechanism by which adrenaline causes the release of plasminogen activator is a passive one (Holemans, 1965), that is to say, the result of anoxia (subsequent to vasoconstriction) or minute trauma (following vasodilatation) of the vascular endothelial units which are believed to be the source of plasminogen activator in the circulation (Todd, 1959). If this is so then the work of West, Sawrey, Bird, Wilson, and Hatcher (1965) may be of interest, for these authors demonstrated a significantly diminished vasoactive response, in terms of calf and foot blood flow, in a group of young diabetics with no clinical evidence of atherosclerosis, following intravenous adrenaline.

In view of the small number of diabetic subjects in this study no attempt has been made to correlate the results with their dosage of insulin, duration of diabetes, and complications. However, our findings emphasize that the study of this aspect of fibrinolysis in diabetic patients may prove to be useful.

We wish to thank all the volunteers; Dr R. A. Cumming, Director of the South-east Scotland Regional Blood Transfusion Centre, for his invaluable help; Dr L. J. P. Duncan, physician in charge of the Diabetic Department, for permission to study his patients; Professor K. W. Donald, Department of Medicine, for the use of the treadmill; Dr D. G. Woodfield for his many helpful suggestions; and $\mathrm{Mr} \mathrm{A}$. G. E. Allan for his technical assistance. This research programme has been supported by a grant from the Scottish Hospital Endowments Research Trust.

\section{REFERENCES}

Astrup, T. (1956). Lancet, 2, 565

Cash, J. D. (1966). Brit. med. J., 2, 502.

$\longrightarrow$, and Allan, A. G. E. (1967). Brit. J. Haemat., 13, 376.

$\longrightarrow$, and Woodfield, D. G. (1967). Nature (Lond.), 215, 628.

Denborough, M. A., and Patterson, B. (1962). Clin. Sci., 33, 485.

Egeberg, D. (1963). Scand. J. clin. Lab. Invest., 15, 533.

Fearnley, G. R. (1965). Fibrinolysis. Arnold, London.

- Chakrabarti, R., and Avis, P. R. D. (1963). Brit. med. J., 1, 921.

Goodman, L. S., and Gilman, A. (1965). The Pharmacological Basis of Therapeutics, 3rd ed. p. 7. Macmillan, New York.

Hardaway, R. M. (1966). Syndromes of Disseminated Intravascular Coagulation. Thomas, Springfield, Ill.

Hathorn, M., Gillman, T., and Campbell, G. D. (1961). Lancet, 1, 1314.

Holemans, R. (1965). Amer. J. Physiol., $20,511$.

Larsson, Y., Persson, B., Sterky, G., and Thoren, C. (1964). Lancet. 1, 350 .

MacKay, N., and Hume, R. (1964). Scot. med. J., 9, 359.

McKay, D. G.(1965). Disseminated Intravascular Coagulation. Hoeber, Harper and Row, New York.

Sandberg, H., Muller, O., Bellet, S., Feinberg, L. J., Gagnon, F., and Gelber, L. (1963). Amer. J. med. Sci., 245, 153.

Tanser, A. R. (1967). J. clin. Path., 20, 231.

Todd, A. S. (1959). J. Path. Bact., 78, 281.

West, R. O., Sawrey, K. R., Bird, G. S., Wilson, D. L., and Hatcher, J. D. (1965). Clin. Sci., 29, 41. 